\title{
Ginsenoside Rh1: A Systematic Review of Its Pharmacological Properties
}

Authors

Dao Ngoc Hien Tam ${ }^{1 *}$, Duy Hieu Truong ${ }^{2 *}$, Thi Thanh Hoa Nguyen ${ }^{3}$, Le Nhat Quynh ${ }^{4}$, Linh Tran ${ }^{2}$, Hong Duong Nguyen ${ }^{5}$, Bahaa eldin Shamandy ${ }^{6}$, Thi Minh Huong Le ${ }^{7}$, Dang Khoa Tran ${ }^{8}$, Dina Sayed ${ }^{9}$, Van Vinh Vu ${ }^{10}$, Shusaku Mizukami ${ }^{11}$,

Kenji Hirayama ${ }^{11}$, Nguyen Tien Huy ${ }^{12,13}$

\section{Affiliations}

1 Faculty of Pharmacy, University of Medicine and Pharmacy, Ho Chi Minh City, Vietnam

2 Institute of Research and Development, Duy Tan University, Da Nang, Vietnam

3 Huy Cuong Pharmaceutical Company, Ho Chi Minh City, Vietnam

4 Hue University of Medicine and Pharmacy, Hue, Vietnam

5 Online Research Club (http://www.onlineresearchclub. org/), Nagasaki, Japan

6 Faculty of Medicine, Aswan University, Aswan, Egypt

7 Tien Giang General Hospital, Tien Giang, Vietnam

8 Vo Truong Toan University, Hau Giang, Vietnam

9 Faculty of Pharmacy, Future University in Egypt, Cairo, Egypt

10 School of Biotechnology, Yeungnam University, Gyeongsan, Republic of Korea

11 Department of Immunogenetics, Institute of Tropical Medicine (NEKKEN), Graduate School of Biomedical Sciences, Nagasaki University, Nagasaki, Japan

12 Evidence Based Medicine Research Group \& Faculty of Applied Sciences, Ton Duc Thang University, Ho Chi Minh City, Vietnam

13 Department of Clinical Product Development, Institute of Tropical Medicine (NEKKEN), Leading Graduate School Program, and Graduate School of Biomedical Sciences, Nagasaki University, Nagasaki, Japan

Key words

ginsenoside Rh1, Panax ginseng, Araliaceae, in vitro, in vivo

received June 5,2017

revised November 15, 2017

accepted November 24, 2017

\section{Bibliography}

DOI https://doi.org/10.1055/s-0043-124087

Published online January 12, 2018 | Planta Med 2018; 84:

139-152 @ Georg Thieme Verlag KG Stuttgart · New York I ISSN 0032-0943

\section{Correspondence}

Associate Professor Nguyen Tien Huy, M.D., Ph.D. Evidence Based Medicine Research Group \& Faculty of Applied Sciences, Ton Duc Thang University 19 Nguyen Huu Tho, Ho Chi Minh City 70000, Vietnam Phone: + 84837755037 , Fax: + 84837755055 nguyentienhuy@tdt.edu.vn

(A) Supporting information available online at http://www.thieme-connect.de/products

\section{ABSTRACT}

Ginsenoside Rh1 is one of major bioactive compounds extracted from red ginseng, which has been increasingly used for enhancing cognition and physical health worldwide. The objective of this study was to review the pharmacological effects of ginsenoside Rh1 in a systematic manner. We performed searches on eight electronic databases including MEDLINE (Pubmed), Scopus, Google Scholar, POPLINE, Global Health Library, Virtual Health Library, the System for Information on Grey Literature in Europe, and the New York Academy of Medicine Grey Literature Report to select the original research publications reporting the biological and pharmacological effects of ginsenoside Rh1 from in vitro and in vivo studies regardless of publication language and study design. Upon applying the inclusion and exclusion criteria, we included a total of 57 studies for our systemic review. Ginsenoside Rh1 exhibited the potent characteristics of anti-inflammatory, antioxidant, immunomodulatory effects, and positive effects on the nervous system. The cytotoxic effects of ginsenoside Rh1 were dependent on different types of cell lines. Other pharmacological effects including estrogenic, enzymatic, anti-microorganism activities, and cardiovascular effects have been mentioned, but the results were considerably diverged. A higher quality of evidence on clinical trial studies is highly recommended to confirm the consistent efficacy of ginsenoside Rh1. 


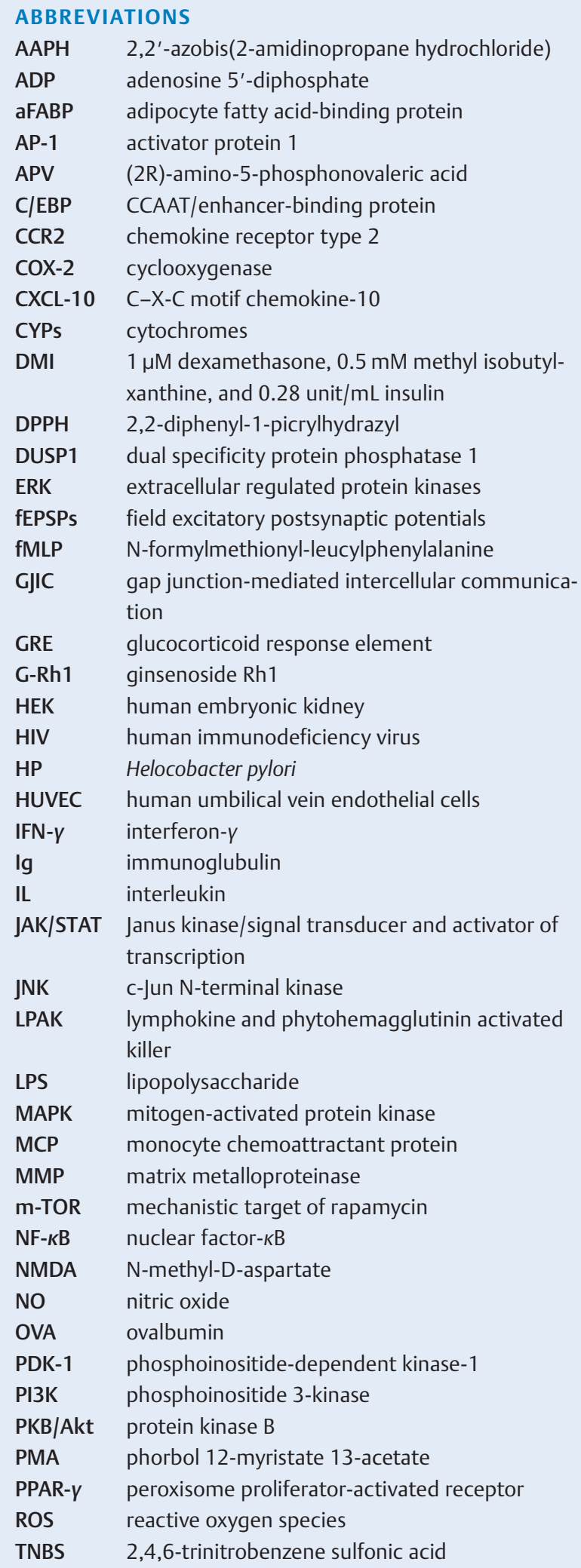

\section{Introduction}

For thousands of years, ginseng has been used as a tonic to invigorate the body and promote longevity, and as an adaptogen for mental and physical stress as well as fatigue in traditional herbal medicine $[1,2]$. It has increasingly achieved more popularity to become one of the most consumed herbal nutritional products worldwide with a total production volume of over 80 thousand tons and total sales of approximately $\$ 2.1$ billion in 2013 [3]. The global ginseng market is also predicted to grow at a compound annual growth rate of around $11.9 \%$ over the next decade and reach approximately $\$ 7.51$ billion by 2025 [4]. Ginseng is a common name for perennial plants of several species belonging to the genus Panax of the family Araliaceae, such as Panax ginseng C. A. Mey., Araliaceae (Asian ginseng), Panax quinquefolius L., Araliaceae (American ginseng), and Panax vietnamensis Ha et Grushv., Araliaceae (Vietnamese ginseng) [5]. With the intention of improving the stability and efficacy reasons, fresh ginseng is often processed by simple drying into white ginseng or steaming and drying into red ginseng. Red ginseng is considered to have a notably higher commercial value than fresh and white ginseng owing to significantly fewer side effects and higher biological effects [6, 7]. According to a clinical trial in premenopausal women, red ginseng has no significant side effect but one adverse event of mild gastric discomfort [8].

Ginsenosides have been found to be the major components of ginseng, which significantly contribute to its precious effects [911]. Based on their chemical structures, ginsenosides can be classified into three principal structural types, namely, protopanaxadiol, protopanaxatriol, and oleanane. More than 40 ginsenosides have been identified and isolated so far $[12,13]$. Their nomenclature is based on the designation of $R x$ and $F x$, where $R$ and $F$ refer to the origin of ginsenosides, namely, roots and leaves ("folia") of the species, respectively, and $x(x=0, a 1, a 2, b 1$, etc.) denotes the order of ginsenosides eluted on thin-layer chromatograms starting with the most hydrophilic ones [14]. Among these compounds, G-Rh1 ( $\vee$ Fig. 1 ) has been found to be one of the main ginsenosides of red ginseng, compared to trace amounts in unprocessed ginseng $[6,15,16]$. Moreover, it has been found that protopanaxatriol-type ginsenosides are mainly hydrolyzed or metabolized to G-Rh1 in the gastrointestinal tract after oral administration of ginseng extracts [17-19]. This compound has been additionally reported to effectively stimulate the central nervous system and enhance mental acuity and intellectual performance [20]. Several studies have shown that G-Rh1 possesses neuroprotective effects, potential antineoplastic effects, and the ability to be adjuvant therapy in chronic inflammatory diseases to dexamethasone [21-23]. Nonetheless, there is no critically evaluated review of the pharmacological effects of G-Rh1 based on summarizing the current reliable evidence. Therefore, the purpose of our study was to systematically review the pharmacological actions of G-Rh1 in the published literature.

\section{Search Strategy}

We performed searches on eight electronic databases including MEDLINE (Pubmed), Scopus, Google Scholar, POPLINE, Global 


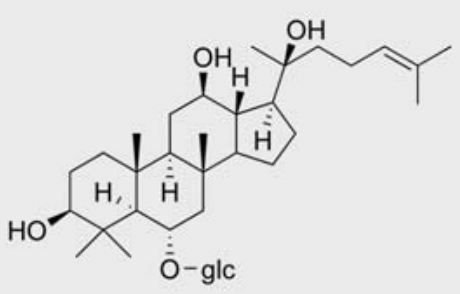

- Fig. 1 Chemical structure of 20(S)-G-Rh1.

Health Library (GHL), Virtual Health Library (VHL), the System for Information on Grey Literature in Europe (SIGLE), and the New York Academy of Medicine Grey Literature Report (NYAM) for original studies published up to August 22, 2015 using the defined search term for each database listed in Table S1, Supporting Information. The inclusion criteria were (i) G-Rh1 as a pure chemical compound alone or combined with other interventions, (ii) in vitro and in vivo studies on human and animal subjects, and (iii) no restriction on language, publication year, and study design. The exclusion criteria were (i) the whole ginseng extract, which contains many different ginsenosides and other components, as the intervention, (ii) book chapters, posters, conference papers, papers without full-text, review articles, and theses, and (iii) overlapped data sets or unreliable extracted data.

We also performed a manual search to obtain relevant papers that were not automatically found in selected databases. In this step, we screened references of full-text papers in the previous step in order to look for potential papers. These papers would be downloaded, read, and data extracted the same as the other papers. Through several steps, as illustrated in $\mathbf{F i g . ~} \mathbf{2}$, we included 57 studies for our systematic review.

\section{Anticancer Effects}

Eleven studies mentioned the effects of G-Rh1 on anticancer activity in vitro ( $\vee$ Table 1 ). Almost all studies used MTT assays to identify cell viability (\%). Kim et al. [24] examined the cytotoxic activity of G-Rh1 in mouse lymphoid neoplasma cell line (P388), human lung carcinoma (A549), and human cervix uterine adenocarcinoma (HeLa). The $\mathrm{IC}_{50}$ of $\mathrm{G}-\mathrm{Rh} 1$ on P388 was $0.037 \mathrm{mM}$, indicating a potent cytotoxic effect on this cell line; meanwhile, these values were higher than $0.1 \mathrm{mM}$ on the other two cell lines, signifying low cytotoxicity. In another study, Wang et al. [25] demonstrated that G-Rh1 could act as an adjuvant to enhance the ability of dendritic cells in stimulating the cytotoxic effects of LPAK in a papilla tumor cell line and $L 929$ cell line through induction of the secretion of IL-12 p40 and transcription of IL-12 mRNA. In the papilla tumor cell line, G-Rh1 significantly improved the cytotoxicity effects of LPAK when the ratio of LPAK and tumor cells was 10:1, even at a concentration as low as $1 \mathrm{mg} / \mathrm{L}$.

Regarding the antiproliferative activity, G-Rh1 was reported to have significant effects on NIH 3 T3 mouse fibroblast cells by inhibiting phospholipase $\mathrm{C}$ and decreasing the intracellular level of diacylglycerol, which is an endogenous activator of protein kinase $C$ [26], and on a human acute monocytic leukemia suspension cell line (THP-1) by increasing apoptosis [27]. In contrast, this compound did not exert pronounced effects on the proliferation of human colon carcinoma (HCT-116), human liver carcinoma (HepG2), HeLa, human breast adenocarcinoma (MCF-7), human pancreatic cancer (PANC-1), human lung carcinoma (A549) [28], and B16 melanoma cells [29], even at the high concentration of $100 \mu \mathrm{M}$. The antiproliferative effects of two stereoisomers were shown to be similar to each other [28]. Consistent with the previous study [24], G-Rh1 exhibited a weak cytotoxic effect on A549 and HeLa cell lines.

Yoon et al. [23] showed that G-Rh1 at concentrations of 50 and $100 \mu \mathrm{M}$ possessed significant antimetastatic properties in HepG2 cells stimulated by PMA via inhibiting MMP-1 transcriptional activity, reducing expression and stability of the AP-1 dimer, c-Fos and c-Jun, and inhibiting MAPK signaling pathways. The mentioned molecular mechanism is somewhat different from that in human astroglioma U87MG and U373MG cells in which G-Rh1 inhibits the invasion and migration of PMA-simulated U87MG cells by suppression of all three types of MAPKs (ERK, JNK, and p38) and DNA binding activities of transcription factors such as NF- $\kappa$ B and AP-1 [30]. In this study, the authors observed a reduction by more than $90 \%$ in the invasiveness after $24 \mathrm{~h}$ treatment with $300 \mu \mathrm{M}$ G-Rh1. In the highly metastatic human fibrosarcoma cell line HT1080, G-Rh1 markedly inhibited the expression of MMP-9, but not MMP-2, the plasminogen activator inhibitor, and the urokinase-type plasminogen activator, suggesting that downregulation of MMP-9 significantly contributed to the anti-invasive effects of this compound [31]. The difference in mechanisms of anti-metastasis of G-Rh1 was supposed to be dependent on the cell type.

Lee et al. [32,33] used F9 teratocarcinoma cells as a model to investigate the ability of ginsenosides to induce differentiation in vitro and the mechanism involved. They found that G-Rh1, along with ginsenoside Rh2, was the most effective differentiation agent in F9 teratocarcinoma cells regarding the induction of morphological change and marker gene expressions (i.e., laminin B1, type IV collagen) [32]. This was in agreement with a previous work of Odashima et al. [29] in B16 melanoma cells in which G-Rh1 stimulated the expression of the melanotic phenotype. In the later work of Lee et al. [33], they experimentally confirmed the involvement of a glucocorticoid receptor in the G-Rh1-induced differentiation process by inducing the nuclear translocation of the glucocorticoid receptor to the nucleus and inducing the GRE transactivation.

In brief, G-Rh1 exerted its cytotoxic effect on three specific cells lines, namely, P388, THP-1, and NIH 3T3 fibroblast cells in a concentration-dependent manner. With regard to the HepG2 cell line, G-Rh1 had no significant antiproliferation ability even with a very high concentration $(80-200 \mu \mathrm{M})$ compared with the other cell lines. The slight cytotoxic effect was seen only with $200 \mu \mathrm{M}$ and $48 \mathrm{~h}$ for incubation.

No study presents the cytotoxicity of G-Rh1 on non-tumoral cell lines, therefore, we could not draw any conclusion about its effects on these cell lines. 


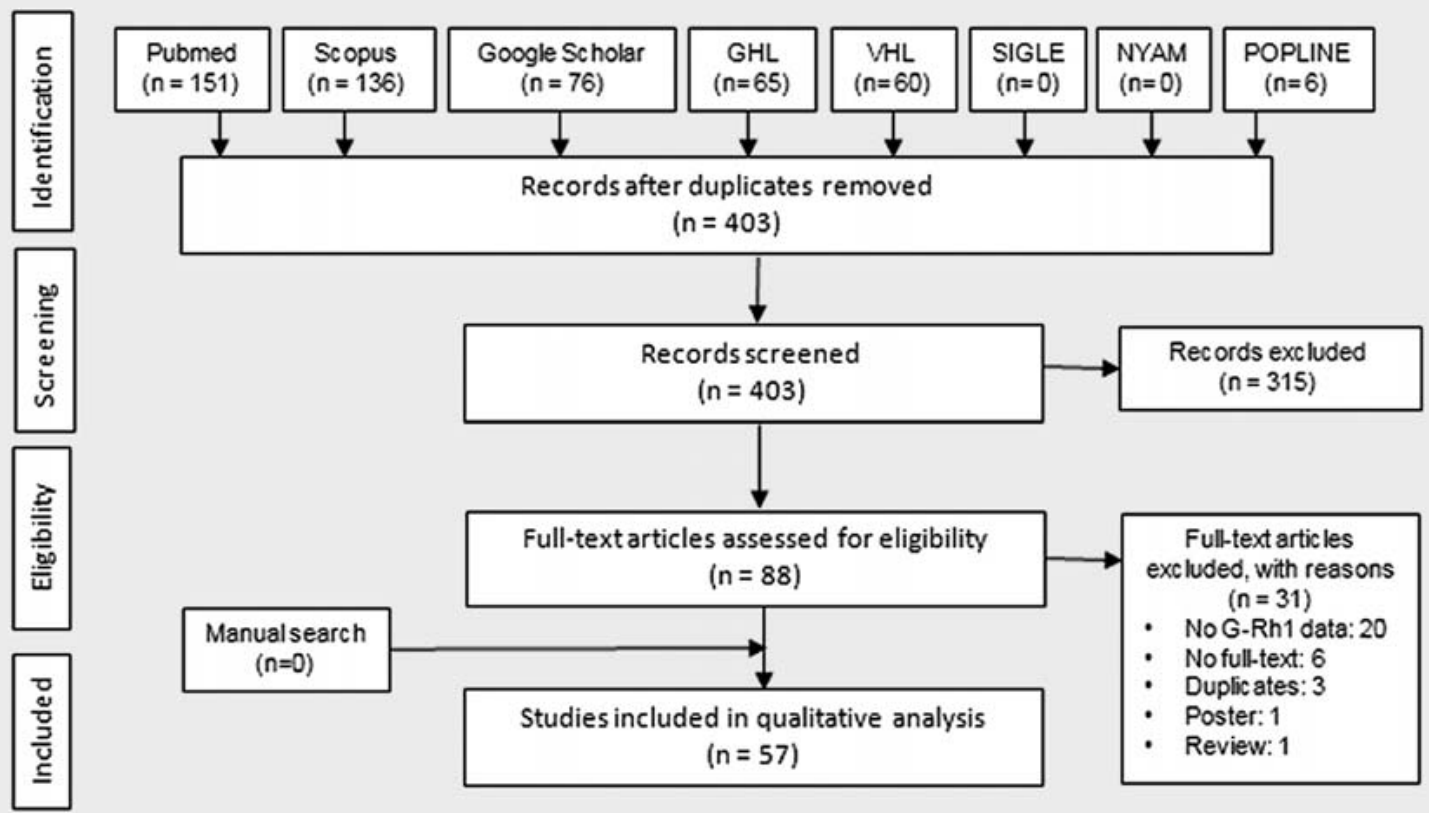

- Fig. 2 The flowchart explaining the process of searching in eight databases, removing duplicates, screening, and qualitative analysis. GHL: Global Health Library, VHL: Virtual Health Library, SIGLE: Systems for Information of Grey Literature in Europe, NYAM: New York Academy of Medicine.

\section{Immunomodulatory Effects}

G-Rh1 has been proven to possess immunomodulatory effects mainly on the inflammatory response on a variety of cell lines in vitro by different mechanisms ( $\triangleright$ Table 2). He et al. [34] reported no significant effect of G-Rh1 in the range of $0.1-10 \mu \mathrm{M}$ on the activity of NF- $\kappa$ B luciferase reporter activity in human embryonic kidney 293 (HEK 293) cells induced by TNF- $\alpha$ (10 ng/mL). However, significant inhibition of NF- $\kappa$ B activation by G-Rh1 was also reported in HEK 293 cells pretreated with TNF- $\alpha$ [35], in BV2 glioma cells induced by LPS [36] or IFN- $\gamma$ [37], in macrophages stimulated by LPS or TNBS [38], and in murine macrophage RAW 264.7 cells treated with LPS [39] or TNF- $\alpha$ [22]. Both He et al. [34] and Xing et al. [35] assessed the protective effect of G-Rh1 on the activation of NF-KB on HEK 293 cells induced by TNF- $\alpha$. However, G-Rh1 seemed not to inhibit NF- $\kappa$ B activation effectively when the higher concentration of TNF- $\alpha$ was used as the stimuli. In addition, G-Rh1 markedly suppressed the CXCL-10 expression in TNF- $\alpha$-induced human promonocytic U937 cells, which may be related to the inactivation of the ERK1/2 signaling pathway [40]. In THP-1 cells, G-Rh1 did not only inactivate ERK1/2, but also attenuated the phosphorylation and activation of MAPK signaling, p38MAPK and JNK activation of PKB/Akt through lowering the expression of MCP-1 and CCR2, and deactivating integrins, the fibronectin receptor VLA-5 and CD29 [21]. Li et al. [22] found that after long-term dexamethasone treatment in RAW264.7 cells, it also induced the activation of DUSP1, resulting in the downregulation of proinflammatory cytokines (IL-6, IL-17, MMP-1, TNF- $\alpha$ ). On THP-1 cells, the effects seemed to depend on the concentrations of G-Rh1 and stimuli, namely, LPS and PMA [41]. G-Rh1 significantly increased the production of TNF- $\alpha$ and its mRNA expression in the presence of LPS at the high dose of $100 \mathrm{mg} / \mathrm{L}$. In contrast, the production of IL- 8 and IL- $1 \alpha$ only increased the low dose of LPS $(10 \mathrm{mg} / \mathrm{L})$ with $1 \mathrm{mg} / \mathrm{L}$ and $100 \mathrm{mg} / \mathrm{L}$ of G-Rh1, respectively [41]. Gu et al. [42] showed that G-Rh1 dose-dependently inhibited the expression of PPAR- $\gamma, C / E B P-\alpha$, and aFABP in DMI-stimulated 3T3L1 adipocytes, thereby, inhibiting adipocyte differentiation and inflammation. In LPS-stimulated RAW 264.7 cells, Park et al. [39] observed a significant reduction in NO synthesis, inducible NO synthase activity, and prostaglandin E2 production at the concentrations of $50 \mu \mathrm{M}$ and $100 \mu \mathrm{M}$ of G-Rh1. G-Rh1 was also found to markedly inhibit NO production in rIFN-y plus LPS-stimulated macrophages [43].

The immunomodulatory effects were also demonstrated by in vivo experiments on various animal models with chemical-induced inflammatory diseases. After oral administration at a dose of $20 \mathrm{mg} / \mathrm{kg}$, G-Rh1 inhibited colon shortening, lowered myeloperoxidase activity, and suppressed the expression of IL-1 $\beta$, IL-17, and TNF- $\alpha$ in mice with TNBS-induced colitis [38], suppressed body weight gain, epididymal fat weight, and plasma triglyceride levels in high-fat diet-induced obesite mice [42], as well as suppressed ear swellings and ear weight, and decreased IL-6 in the serum of hairless mice with atopic dermatitis-like skin lesions [44]. Gu et al. [42] indicated the effective attenuation of body weight gain, epididymal fat weight, and plasma triglyceride levels in obese mice. Nevertheless, relevant baseline characteristics (e.g., initial body weight, triglyceride level) or equivalent characteristics between control groups and intervention groups were not presented. Oral administration of G-Rh1 at different doses of $10 \mathrm{mg} /$ $\mathrm{kg}$ and $25 \mathrm{mg} / \mathrm{kg}$ markedly suppressed the expression of cytokines 
- Table 1 Summary of anticancer activities of G-Rh1.

\begin{tabular}{|c|c|c|c|c|}
\hline Experimental model & Method & Effects & Mechanism & Ref. \\
\hline \multirow[t]{2}{*}{$\begin{array}{l}\text { HepG2 human hepatocellular } \\
\text { carcinoma cells }\end{array}$} & XTT assay & $\begin{array}{l}\text { Slight cytotoxicity (at } 200 \mathrm{mM} \\
\text { for } 48 \mathrm{~h} \text { ) }\end{array}$ & & \multirow[t]{2}{*}{$\begin{array}{l}\text { Yoon et al. } \\
\text { [23] }\end{array}$} \\
\hline & Cell-matrix adhesion assay & $\begin{array}{l}\text { Significant inhibition of invasion } \\
\text { and migration }\end{array}$ & $\begin{array}{l}\text { Inhibit MMP-1 transcrip- } \\
\text { tional activity, reduce ex- } \\
\text { pression and stability of the } \\
\text { AP-1 dimer, c-Fos and c-Jun, } \\
\text { and inhibit MAPK signaling } \\
\text { pathways }\end{array}$ & \\
\hline $\begin{array}{l}\text { P388 mouse lymphoid neo- } \\
\text { plasma cells, A549 human lung } \\
\text { carcinoma, HeLa human cervix } \\
\text { uterine adenocarcinoma cells }\end{array}$ & MTT assay & $\begin{array}{l}\text { Potent cytotoxic effect on P388 } \\
\text { cells; low cytotoxic effect on A549 } \\
\text { and HeLa cells }\end{array}$ & & $\begin{array}{l}\text { Kim et al. } \\
{[24]}\end{array}$ \\
\hline $\begin{array}{l}\text { Papilla tumor cell line, } \\
\text { L929 cell line }\end{array}$ & Neural red staining assay & $\begin{array}{l}\text { Enhance the ability of dendritic cells } \\
\text { (DC) to stimulate the cytotoxic } \\
\text { activity of dendritic cell lympho- } \\
\text { kine- and phytohemagglutinin- } \\
\text { activated killer (DC- LPAK) }\end{array}$ & & $\begin{array}{l}\text { Wang et al. } \\
\text { [25] }\end{array}$ \\
\hline NIH $3 \mathrm{~T} 3$ fibroblast cells & $\begin{array}{l}\text { Measurement of replicative } \\
\text { DNA synthesis and intracellular } \\
\text { DAG contents, protein kinase C } \\
\text { assay, phospholipase } C \text { assay }\end{array}$ & Antiproliferative effect & $\begin{array}{l}\text { Inhibit phospholipase C, } \\
\text { which produces second } \\
\text { messengers necessary for } \\
\text { the activation of protein } \\
\text { kinase C }\end{array}$ & $\begin{array}{l}\text { Byun et al. } \\
{[26]}\end{array}$ \\
\hline THP-1 human leukemia cells & MTT assay; flow cytometry & $\begin{array}{l}\text { Antiproliferative effect, } \\
\text { proapoptotic effect }\end{array}$ & & $\begin{array}{l}\text { Popovich and } \\
\text { Kitts [27] }\end{array}$ \\
\hline $\begin{array}{l}\text { HCT-116 human colon carcino- } \\
\text { ma cells, HepG2 human hepa- } \\
\text { tocellular carcinoma cells, } \\
\text { HeLa cervical cancer cells, } \\
\text { MCF-7 breast cancer cells, } \\
\text { A549 human lung carcinoma } \\
\text { cells, PANC-1 human pancreatic } \\
\text { carcinoma cells }\end{array}$ & MTT assay & $\begin{array}{l}\text { Did not show remarkably antipro- } \\
\text { liferation ability in these cell lines }\end{array}$ & & $\begin{array}{l}\text { Quan et al. } \\
{[28]}\end{array}$ \\
\hline B16 melanoma cells & Assay of growth inhibition & $\begin{array}{l}\text { Did not show remarkably antipro- } \\
\text { liferation ability in these cell lines }\end{array}$ & & $\begin{array}{l}\text { Odashima } \\
\text { et al. [29] }\end{array}$ \\
\hline HT1080 fibrosarcoma cells & In vitro invasion assay & Anti-invasive effect & & $\begin{array}{l}\text { Park et al. } \\
{[31]}\end{array}$ \\
\hline F9 teratocarcinoma cells & $\begin{array}{l}\text { Phase-contrast microscopy, } \\
\text { electrophoretic mobility shift } \\
\text { assay, transient transfection } \\
\text { assay }\end{array}$ & Cause the differentiation of F9 cells & $\begin{array}{l}\text { Form a complex with ste- } \\
\text { roid receptors, which might } \\
\text { regulate the expression of } \\
\text { proteins that have an im- } \\
\text { portant role in the differen- } \\
\text { tiation process of F9 cells }\end{array}$ & Lee et al. [32] \\
\hline F9 teratocarcinoma cells & Immunolocalization & Induce the differentiation of F9 cells & $\begin{array}{l}\text { Stimulating the nuclear } \\
\text { translocation of GR }\end{array}$ & Lee et al. [33] \\
\hline $\begin{array}{l}\text { U87MG and U373MG human } \\
\text { astroglioma cells }\end{array}$ & $\begin{array}{l}\text { Matrigel invasion assay, } \\
\text { wound healing assay }\end{array}$ & $\begin{array}{l}\text { Inhibit the invasion and migration } \\
\text { of U87MG and U373MG glioma } \\
\text { cells }\end{array}$ & $\begin{array}{l}\text { Suppress all three types of } \\
\text { MAPKs (ERK, JNK, and p38) } \\
\text { and DNA-binding activities } \\
\text { of transcription factors } \\
\text { such as NF-KB and AP-1 }\end{array}$ & $\begin{array}{l}\text { Jung et al. } \\
\text { [30] }\end{array}$ \\
\hline
\end{tabular}

such as TNF- $\alpha$ and IL-4 compared to a histamine-induced control in mice by inhibiting the activation of transcription factors NF- $k B$ and c-jun (AP-1) in histamine-induced skin tissues [45]. It remains ambiguous on the role of G-Rh1 in the regulation of the Th1/Th2 balance through controlling the expressions of IFN- $y$ and IL-4. Zheng et al. [44] showed that oral administration of $20 \mathrm{mg} / \mathrm{kg} /$ day G-Rh1 in mice upregulated the expression of IFN-y and Foxp3, but did not reduce IL-4 levels. These results suggest that the improved symptoms of skin lesions were partly related to the reduction of IgE, which might have come from the upregulation of IFN-y expression. However, this contradicted to the later work of Feng et al. [46] in which they reported that G-Rh1 decreased IFN- $\gamma$ mRNA 
- Table 2 Summary of anti-inflammatory activities of G-Rh1.

\begin{tabular}{|c|c|c|c|}
\hline Experimental model & Method & Mechanism & Ref. \\
\hline THP-1 cells & ELISA & & Choi et al. [21] \\
\hline RAW 264.7 cells & $\begin{array}{l}\text { Proinflammatory mediators } \\
\text { determination assays }\end{array}$ & $\begin{array}{l}\text { Repressed the expression of IL-6, IL-17, } \\
\text { MMP-1, and TNF- } \alpha\end{array}$ & Li et al. [22] \\
\hline $\begin{array}{l}\text { HEK293 Human embryonic } \\
\text { kidney cells }\end{array}$ & $\begin{array}{l}\text { NF- } \kappa \text { B activity luciferase reporter } \\
\text { assay }\end{array}$ & & Xing et al. [35] \\
\hline RAW 264.7 cells & Western blot analysis & $\begin{array}{l}\text { Suppressed the factors that were associ- } \\
\text { ated with the inflammatory processes } \\
\text { (NO production, COX-2 protein, PEG } 2 \text { ex- } \\
\text { pression, iNOS protein, iNOS activity, } \\
\text { and the activation of NF- } \mathrm{kB} \text { transcription } \\
\text { factor) }\end{array}$ & Park et al. [39] \\
\hline $\begin{array}{l}\text { U937 Human promonocytic } \\
\text { cells }\end{array}$ & RT-PCR & $\begin{array}{l}\text { Significantly inhibited TNF- } \alpha \text {-induced } \\
\text { CXCL-10 expression }\end{array}$ & Lee et al. [40] \\
\hline THP-1 cells & Radioimmunoassay, RT-PCR & & Wang et al. [41] \\
\hline Male C57BL/6] mice & RT-PCR & $\begin{array}{l}\text { Rh1 suppressed inflammatory factors } \\
\text { (TNF- } \alpha, \text { IL- } 1 \beta, \text { IL- } 6 \text { ) in the blood of obese } \\
\text { mice }\end{array}$ & Gu et al. [42] \\
\hline $\begin{array}{l}\text { Thioglycollate-elicited } \\
\text { macrophage }\end{array}$ & Griess & Markedly reduced the production of NO & Park et al. [43] \\
\hline Female hairless mice & ELISA, RT-PCR & $\begin{array}{l}\text { Reduced IgE and IL- } 6 \text { levels in peripheral } \\
\text { blood, increased Foxp } 3 \text { expression, and } \\
\text { inhibited the inflammation in skin regions }\end{array}$ & Zheng et al. [44] \\
\hline Male ICR mice & Ear thickness & $\begin{array}{l}\text { Potently suppressed TPA- and oxazolone- } \\
\text { induced swelling }\end{array}$ & Shin et al. [49] \\
\hline Murine BV2 microglia cells & RT-PCR & $\begin{array}{l}\text { Suppressed proinflammatory cytokines } \\
\text { (TNF- } \alpha \text {, IL-6, MCP-1), COX-2, MCP-1, MMP- } \\
3 \text {, and MMP-9, and enhanced anti-inflam- } \\
\text { matory cytokines (IL-10) }\end{array}$ & Jung et al. [50] \\
\hline Male C57BL/6 mice & Immunofluorescence & $\begin{array}{l}\text { G-Rh1 markedly decreased the number of } \\
\text { OX-42-positive activated cells in the cor- } \\
\text { tex, hippocampus, and substantia nigra of } \\
\text { the brain that was inflamed by LPS }\end{array}$ & \\
\hline
\end{tabular}

and increased IL-4 mRNA levels. In this study, they also found that potential G-Rh1 $(25 \mathrm{mg} / \mathrm{kg} /$ day intraperitoneally) in combination with dexamethasone $(1 \mathrm{mg} / \mathrm{kg} /$ day) significantly decreased proteinuria levels and the levels of anti-dsDNA and anti-ANA autoantibodies compared to those of dexamethasone alone in MRL/Ipr mice, suggesting that G-Rh1 might potentiate the effects of dexamethasone in the treatment of systemic lupus erythematosus [46]. As for other immunoglobulins, G-Rh1 was shown to significantly enhance OVA-specific $\lg G, \lg G 1, \lg G 2 a$, and $\lg G 2 b$ antibody levels in OVA-immunized mice compared to the OVA group [47]. Besides, G-Rh1 was shown to significantly inhibit the IgE-dependent passive cutaneous anaphylaxis reaction in mice after administered $25 \mathrm{mg} / \mathrm{kg}$ orally or intraperitoneally [39]. In systemic anaphylactic shock model induced by $8 \mathrm{mg} / \mathrm{kg}$ of compound $48 / 80$, pretreatment of G-Rh1 $(5 \mathrm{mg} / \mathrm{kg}$ ) considerably lowered the overall mortality rate [48]. Intraperitoneal administration of a higher dose of $50 \mathrm{mg} / \mathrm{kg}$ could significantly reduce the number of activated OX-42-positive cells in the cortex, hippocampus, and substantia nigra of the brain, as well as lower the immune reactivity of Iba1 and IL-1 $\beta$ expression in the cortex [36]. Topically applied 0.01 and
$0.05 \%$ G-Rh 1 potently reduced the ear thickness in 12-O-tetradecanoylphorbol-13-acetate- and oxazolone-induced mouse dermatitis models and lowered the expression levels of COX-2, IL- $1 \beta$, and TNF- $\alpha$ [49]. When combined with dexamethasone, G-Rh1 $(10 \mathrm{mg} /$ $\mathrm{kg}$ ) showed superior anti-inflammatory potential with a lower mean clinical severity in comparison with dexamethasone alone in collagen-induced arthritis mouse model [22].

\section{Antioxidant Effects}

The antioxidant effects of G-Rh1 are summarized in > Table 3. It was shown that pretreatment with G-Rh1 at the concentrations of $100 \mu \mathrm{M}$ and $300 \mu \mathrm{M}$ for $1 \mathrm{~h}$ significantly suppressed ROS production in BV2 cells stimulated by LPS $(0.1 \mu \mathrm{g} / \mathrm{mL})$ [50] or IFN- $\gamma$ $(100 \mathrm{U} / \mathrm{mL})$ [37]. On myocardiocytes from Wistar rats, G-Rh1 $(30 \mu \mathrm{M})$ decreased the free radical content of myocardiocytes by more than $50 \%$ after incubation with xanthine-xanthine oxidase for 5 days [51]. Using the $2^{\prime}, 7^{\prime}$,-dichlorofluorescin diacetate assay, the intracellular ROS scavenging activity of G-Rh1 was determined to be $45 \%$ at $10 \mu \mathrm{M}$ compared to $90 \%$ in the case of the same dose 
- Table 3 Summary of antioxidant activities of G-Rh1.

\begin{tabular}{|c|c|c|c|c|}
\hline Experimental model & Method & Effects & Mechanism & Ref. \\
\hline BV2 microglial cell & iNOS reporter gene assay & Antioxidant & $\begin{array}{l}\text { Significantly suppressed IFN-c-induced } \\
\text { iNOS promoter activity by inhibiting DNA } \\
\text { binding of several transcription factors, } \\
\text { such as NF-kB, IRF-1, and STAT1; inhibited } \\
\text { the phosphorylation of JAK1, STAT1, } \\
\text { STAT3, and ERK }\end{array}$ & Jung et al. [36] \\
\hline BV2 microglial cell & Western blot analysis & Antioxidant & $\begin{array}{l}\text { Induced activation of the cAMP response } \\
\text { element binding protein (CREB) }\end{array}$ & Jung et al. [50] \\
\hline Myocardiocyte & Spin number & Antioxidant & $\begin{array}{l}\text { Antagonized the increase of free radical } \\
\text { content induced by xanthine or xanthine } \\
\text { oxidase }\end{array}$ & Jiang et al. [51] \\
\hline $\begin{array}{l}\text { V79-4 Chinese hamster } \\
\text { lung fibroblast cells }\end{array}$ & $\begin{array}{l}2^{\prime}, 7^{\prime}, \text {-Dichlorofluorescin } \\
\text { diacetate method }\end{array}$ & Antioxidant & Scavenged reactive oxygen species & Chae et al. [52] \\
\hline $\begin{array}{l}\text { Human polymorpho- } \\
\text { nuclear leukocytes }\end{array}$ & Superoxide generation & Antioxidant & $\begin{array}{l}\text { Suppressed stimulus-induced superoxide } \\
\text { generation of neutrophils }\end{array}$ & He et al. [53] \\
\hline Human erythrocyte & Hemolysis assay & $\begin{array}{l}\text { Prooxidant, but synergis- } \\
\text { tic antioxidative interac- } \\
\text { tion with } \alpha \text {-tocopherol }\end{array}$ & Not defined & Liu et al. [54] \\
\hline Human erythrocyte & Hemolysis assay & Antioxidant & Not defined & Liu et al. [55] \\
\hline Human erythrocyte & Hemolysis assay & Antioxidant & Not defined & Li et al. [56] \\
\hline Human erythrocyte & $\begin{array}{l}\text { SH group content in } \\
\text { erythrocyte membrane }\end{array}$ & Antioxidant & Not defined & $\begin{array}{l}\text { Samukawa } \\
\text { et al. [57] }\end{array}$ \\
\hline
\end{tabular}

of $\mathrm{N}$-acetylcysteine as a positive control [52]. He et al. [53] compared the inhibitory effects of five ginsenosides (Rb1, Rb2, Rd, Rh1, Rh2) on superoxide generation induced by fMLP, PMA, and arachidonic acid in human neutrophils. They found that G-Rh1 slightly suppressed PMA- and arachidonic acid-induced superoxide generation, but strongly inhibited the fMLP-stimulated process at a higher extent than the four other ginsenosides. Moreover, it exhibited almost no effect on the lipid peroxidation level concentrations up to $200 \mu \mathrm{M}$, suggesting the mechanism of action is to suppress stimulus-induced superoxide generation of neutrophils rather than scavenge generated free radicals. They also performed experiments with the DPPH assay and confirmed that G-Rh1 did not possess a scavenging effect. To explain this, Chae et al. [52] supports that the DDPH assay is not an appropriate method to identify antioxidant effects of ginsenosides because they are not electron-rich compounds to donate their electron to DPPH. Their antioxidant ability should be examined through measuring the activity of free radicals, hydroxyl, ROS, etc.

Although Jung et al. [37] measured intracellular ROS production, the used concentration was extremely higher than in the other ones. This is because they aimed to investigate a neuroprotective effect of G-Rh1 and its mechanism of action. In addition, ROS plays a role as a messenger of the inflammatory process. Therefore, they chose concentrations of G-Rh1 according to the minimum effective concentrations causing the other effects.

Interestingly, Liu et al. [54] found that G-Rh1 was a prooxidant when the lag time of hemolysis decreased at high concentrations of G-Rh1 (i.e., 10-25 $\mathrm{MM}$ ), but they observed its synergistic antioxidative properties with $\alpha$-tocopherol using an AAPH-induced hemolysis model on human erythrocytes. The same group of authors, however, concluded that G-Rh1 was an antioxidant when it decreased the hemolysis percentages in another study [55]. They supposed that this difference might come from whether glucose was present in the phosphate buffered saline systems or not. Using the hemolysis test, its antioxidative activity could be expressed by the linear equation $\mathrm{H}=-0.703 \mathrm{C}+83.1$, in which $\mathrm{H}$ and $C$ referred to the hemolysis percentage and its concentration, respectively [55]. Its antioxidative activity was further confirmed by two other researches [56,57]. Li et al. [56] showed the hemolysis percentage reduced to $74 \pm 11 \%$ at $20 \mu \mathrm{M} \mathrm{G}$-Rh1 compared to $100 \%$ in the case of the control in hemin-induced hemolysis. One study stated that G-Rh1 significantly attenuated the decrease in thiol groups of band 3 protein in the erythrocyte membrane by inhibiting the oxidation of these groups in the cysteine residues [57]. Considering band 3 protein as a structural protein determining the stability and flexibility of erythrocytes, treatment with G-Rh1 could protect the rheological functions of erythrocytes. Unexpectedly, the authors showed that G-Rh1 did not exhibit the antioxidant effect using 2-methyl-6-methoxy phenylethynylimidazopyrazynone. The reason was probably due to the liposolubility of G-Rh1 as it could not display the effect in the aqueous phase of the 2-methyl-6-methoxy phenylethynylimidazopyrazynone reaction kit.

\section{Effect on Nervous Systems}

By the passive avoidance test, pretreatment of G-Rh1 at doses of 5 and $10 \mathrm{mg} / \mathrm{kg}$ was observed to significantly improve the learning 
and memory in mice with scopolamine-induced memory impairment [58] or saline-treated mice [59]. In the Morris water maze test, G-Rh1 $(10 \mathrm{mg} / \mathrm{kg})$ markedly decreased the escape latency, and increased the number of crosses and the time spent in the platform, thereby improving the spatial learning ability [59]. Moreover, Wang et al. [58] found that the pain threshold was not affected in the tail-flick test, confirming the nootropic effect of G-Rh1.

Lee et al. [60] compared the effects of seven ginsenosides on neural activity by measuring changes in the slope of fEPSPs. At the concentration of $100 \mu \mathrm{g} / \mathrm{mL}$, G-Rh1 was moderately effective $(46.1 \pm 6.7 \%)$ in suppressing fEPSPs. The complete abolition of fEPSPs could be observed in the case of the non-NMDA receptor antagonist 6-cyano-7-nitroquinoxaline-2,3-dione, but not the NMDA receptor antagonist (2R)-amino-5-phosphonovaleric acid. This might suggest that G-Rh1 exerted its effects by regulating the non-NMDA receptor-mediated synaptic activity.

The neuroprotective effects of G-Rh1 were reported on neuroblastoma SH-SY5Y cells and pheochromocytoma PC-12 cells [20]. $\mathrm{G}-\mathrm{Rh} 1$ at the concentrations of 10 and $20 \mu \mathrm{M}$ significantly attenuated the toxicity on SH-SY5Y cells exposed to $60 \mu \mathrm{M}$ of sixhydroxydopamine. This was partially because of the reduction of ERK1/2 phosphorylation by G-Rh1 pretreatment, as could be seen in other cell lines such as HepG2, U87MG, U937, and THP-1 cells $[21,23,30,40]$. G-Rh1 increased the percentage of PC-12 cells with neurites compared to that of the control. However, no apparent difference was observed between the two stereoisomers 20(S)-G-Rh1 and 20(R)-G-Rh1, suggesting the C-20 stereochemistry may not have a role in the neuroprotective effect.

\section{Estrogenic Activity}

Three papers reported estrogenic activity of G-Rh1 in vitro using the human breast cancer MCF-7 cell line. Dong et al. [61] observed that G-Rh1 stimulated cell proliferation in a dose-dependent manner, reaching a significant level at $100 \mu \mathrm{M}$ with a significant correlation $(r=0.218, p<0.05)$ between G-Rh1 and $17 \beta$-estradiol in the expression profiles after treatment of MCF-7 cells with these two compounds. Lee et al. [62] demonstrated that $\mathrm{G}-\mathrm{Rh} 1$ bound to and activated the estrogen receptor at an extent of 5000 - to 10000 -fold weaker than that of $17 \beta$-estradiol. In the work of Bae et al. [63], the proliferation of MCF-7 cells increased 2.1-fold at the concentration of $1 \mu \mathrm{M}$ of G-Rh1 to reach the same level as $1 \mathrm{nM}$ of $17 \beta$-estradiol. The expressions of $\mathrm{c}$-fos and pS2 genes were also slightly induced in the presence of G-Rh1, as previously reported [62]. Taken together, these data consistently demonstrated G-Rh1 as a weak estrogenic compound.

\section{Other Pharmacological Effects}

Four studies investigating the enzymatic activities of G-Rh1 have been performed. Liu et al. [64] examined the effects of G-Rh1 on human CYPs. They witnessed the moderate inhibition on CYP3A4 ( $\mathrm{IC}_{50}$ of $\left.76.9 \pm 6.8 \mu \mathrm{M}\right)$ by competitive inhibition of testosterone $6 \beta$-hydroxylation in CDNA-expressed CYP3A4 and weak stimulation on CYP2E1. However, no significant effects was observed on CYP1A2, CYP2A6, CYP2A9, and CYP2D6, even at $100 \mu \mathrm{M}$.
Etheridge et al. [65] found G-Rh1 ranging from 1 to $10 \mu \mathrm{M}$ did not affect the activities of CYP1A2, CYP2C8, CYP2C9, CYP2C19, CYP2D6, and testosterone $6 \beta$-hydroxylase. At the concentration of $10 \mu \mathrm{M}, \mathrm{G}-\mathrm{Rh} 1$ suppressed midazolam 1-hydroxylase activity by $54 \%$ and increased P-glycoprotein ATPase activity to $17.2 \mathrm{nmol} \mathrm{P}_{\mathrm{i}} /$ $\mathrm{mg}$ protein/min, but it exerted negligible effects on these at the low concentration of $1 \mu \mathrm{M}$. In contrast, Li et al. [66] found weak inhibitory activity of G-Rh1 on P-glycoprotein by $8.94 \%$ at $75 \mu \mathrm{M}$ using a transport assay on Caco-2 cells. In agreement with the two abovementioned works, G-Rh1 was confirmed as a CYP3A4 inhibitor owing to $15 \%$ suppression of midazolam metabolism at $10 \mu \mathrm{M}$. In another enzymatic system in 3T3-L1 adipocytes, G-Rh1 at the concentration of $100 \mu \mathrm{g} / \mathrm{mL}$ enhanced the lipoprotein lipase activity in the medium by $32 \%$, whereas it exerted no effect on cellular lipase activity [67].

The anti-microorganism activity of Rh1 was mentioned in two in vitro studies. Bae et al. [68] showed that G-Rh1 did not inhibit the growth of four different strains of HP, even at the high concentration of $100 \mu \mathrm{g} / \mathrm{mL}$. However, G-Rh1 (1 mM) did show weak inhibition of HP urease and stomach $\mathrm{H}^{+} / \mathrm{K}^{+}$ATPase by 5 and $15 \%$, respectively. Jeong et al. [69] examined the anti-HIV activity of G-Rh1 by its effects against cytoprotection on Tat-expressing CHME5 cells and HIV infected macrophages. G-Rh1 increased cell death in the presence of LPS/cycloheximide dose-dependently, although G-Rh1 or LPS/cycloheximide alone did not affect it significantly. The mechanism was supposed to inhibit Akt, glycogen synthase kinase $3 \beta, \mathrm{m}-\mathrm{TOR}$, PDK-1 phosphorylation, and BAD activation in the PI3K/Akt pathway. The synergistic anti-cytoprotective effects of G-Rh1 and miltefosine ( 5 or $10 \mu \mathrm{M}$ ), which is a $\mathrm{PI} 3 \mathrm{~K} /$ Akt phosphorylation inhibitor used for treatment of HIV-1 dementia, on Tat-transduced CHME5 cells were also observed.

The cardiovascular effects of G-Rh1 were reported in three studies. G-Rh1 $(60 \mu \mathrm{mol} / \mathrm{L})$ affected the basic functions of myocardiocytes by reducing the open times, increasing the close times, and reducing the open-state probabilities of all three types (i.e., B, L, and T) of calcium channels [51]. These effects were slightly different to those of two calcium antagonists, verapamil and Bay K 8644, in which these positive controls showed no activity on the T-type calcium channel. In the work of Gai et al. [70], pretreatment of G-Rh1 at the dose of $10 \mathrm{mg} / \mathrm{kg}$ for 7 days decreased the activity of CK-MB and troponin T level, and significantly alleviated the increase of left ventricular end-diastolic pressure and the decrease of left ventricular systolic pressure and \pm $\mathrm{dp} / \mathrm{dt}$ in isoproterenol-induced myocardial infracted rats. This might suggest that G-Rh1 could ameliorate heart function impairment. Lee et al. [71] reported that G-Rh1 at the nontoxic dose of $25 \mu \mathrm{M}$ exhibited marked attenuation of the monocyte adhesion of HUVEC exposed to $10 \mathrm{ng} / \mathrm{mL}$ of TNF- $\alpha$. G-Rh1 also substantially inhibited adhesion molecules such as VCAM-1, ICAM-1, and E-selectin in TNF- $\alpha$-stimulated HUVEC, and suppressed the induction of $\alpha 4 / \beta 1$ integrin VLA-4 and $\alpha 4 / \beta 2$ integrin LFA- 1 in TNF- $\alpha$-stimulated THP-1 monocytes. However, G-Rh1 did not disturb the NF- $\kappa$ B signaling pathway; therefore, the authors supposed that the antiatherogenic activity of G-Rh1 related to the monocyte adhesion to activated endothelium may be JAK/STAT and/or ERK responsive as Jung et al. [37] mentioned previously. 
The cholesterol-like structure of G-Rh1 inspired Lee et al. [72] to explore whether G-Rh1 could substitute cholesterol in the growth of Caenorhabditis elegans. These nematodes were fed in medium with cholesterol, without cholesterol, or cholesterol-deprived medium supplemented G-Rh1, and the growth rate (i.e., time for eggs to reach adults) was appraised. In the absence of cholesterol, worms grew slowly, expressing that the growth rate of worms from eggs to young adults or from young adults to adults were greatly retarded in both the F1 and F2 generations. Nevertheless, adding G-Rh1 into cholesterol-deprived medium could improve in F1 generation, not only the growth rate of all stages but also the worm length. In F2 generation, the addition of G-Rh1 into the cholesterol abolished medium could not recover the growth rate, only the worm length was recovered.

Tachikawa et al. [73] studied the inhibitory effect of ginsenosides on catecholamine secretion from bovine adrenal chromaffin cells. Upon stimulation by $50 \mu \mathrm{M}$ of acetylcholine, G-Rh1 showed intermediate inhibition of $39 \%$ in comparison with the most potent inhibitor of ginsenoside Rg2 with $72 \%$ at the same concentration of $10 \mu \mathrm{M}$.

Using mouse osteoblastic MC3T3-E1 cell line as an in vitro model, Siddiqi et al. [74] showed that this compound possessed osteoblast differentiation and osteogenic stimulatory activity. G-Rh1 in the range of $1-300 \mu \mathrm{M}$ significantly stimulated the osteoblastic MC3T3-E1 cell viability, and improved cell differentiation and mineralization, which was extended for up to 28 days. The mechanism of action was determined to be due to the upregulation of osteogenic markers such as alkaline phosphatase, type-I collagen, and osteocalcin via bone morphogenetic protein 2/Runt-related gene 2 signaling pathways.

Matsuda and colleagues [75] tested the effects of two stereoisomers $(20 S, 20 R)$ of G-Rh1 on blood platelet aggregation induced by collagen or ADP and conversion of fibrinogen to fibrin. They found that 20(R)-G-Rh1 showed a higher inhibitory activity on blood platelet aggregation than the 20(S)-G-Rh1 counterpart. In contrast, the trend was reversed on conversion of fibrinogen to fibrin when 20(S)-G-Rh1 required a longer time to clot. The effects of two abovementioned isomers on GJIC, which plays a crucial role in the many complex cellular processes, was investigated by Zhang et al. [76]. Both isomers significantly suppressed the GJIC function at a concentration of $10 \mu \mathrm{M}$, but the mechanism seemed to be different. 20(S)-G-Rh1 inhibited GJIC via tyrosine kinase activation, whilst GIIC reductions induced by 20(R)-G-Rh1 were owing to both tyrosine kinase and protein kinase $C$.

\section{Methodological Quality of Studies}

The methodological quality of included animal studies was assessed ( $\vee$ Table 4 ) by using criteria from SYRCLE's tool [77]. This tool contains 10 items: sequence generation (selection bias), baseline characteristics (selection bias), allocation concealment (selection bias), random housing (performance bias), blinding (performance bias), random outcome assessment (detection bias), blinding (detection bias), incomplete outcome data (attrition bias), selective outcome reporting (reporting bias), and other sources of bias (other bias). Risks of bias of each item were detected by answering some questions in relation to the method.
The symbol " $\sqrt{ }$ " shows a low risk of bias, symbol " $x$ " shows a high risk of bias, and symbol "?" shows an unclear risk of bias. We only judged and reported the levels of risks of bias for each item through the response of individual questions. There was no general conclusion for quality of the whole study. There are six studies that claimed the animals were divided randomly $[22,44,50,58$, $59,70]$. However, no study presented any method to generate the allocation sequence.

Regarding the baseline characteristic item, seven studies showed the balance of relevant baseline characteristics between the control group and the intervention group [38,45,47, 48, 50, $58,59]$. No study noted any adjustment if the unequal distribution of some relevant baseline characteristics in analysis had existed. In addition, the time to induce disease of all studies was inadequate.

Some signals indicated an unclear risk of bias, such as no report of the allocation concealment and the random outcome assessment. Moreover, only one study reported the number of animals in analysis while the rest did not mention this [46]. In consequence, attrition bias of almost studies are unclear.

The blinding process for investigators and assessors was even not ensured. Nevertheless, only one study showed that its outcome would be biased due to not complying with this process [58]. We determined this outcome was due to their measurement being dependent on a subjective awareness of the assessors.

Although all of the authors did not give information whether they placed the cages or animals randomly in the room/facility, we made a consensus that the results were not skewed by the non-randomization because all studies followed a standard guideline. There is no protocol available, but all outcomes mentioned in the results part are the same compared with the methods in the publication.

With regard to other biases, all studies presented that contamination and design-specific risks of bias were absent. Four trials provided information about conflicts of interest $[38,45,46,70]$. Finally, we have no details to verify unit of analysis errors and whether new animals had been added to replace dropouts from the original population.

\section{Discussion}

The present study demonstrated that G-Rh1 exhibited a wide range of pharmacological effects including anti-inflammation, antioxidation, immunomodulation, and positive effects on cognitive functions. This could partly elucidate some of the precious activities of ginseng on cardiovascular risk factors [78], hypertension [79], Alzheimer's disease [80], and cognitive function [81]. Together with the low toxicity in normal cells or in animal models $[47,53,82]$ as well as high liposolubility and high permeability through the blood brain barrier, G-Rh1 could be a compound of interest when developing a therapeutic regime for treatment of central nervous system diseases [20, 50, 58, 59].

G-Rh1 expressed its antioxidant effects by reducing ROS production or suppressing superoxide generation in neutrophils stimulated by $\mathrm{H}_{2} \mathrm{O}_{2}$, LPS, IFN- $\gamma$, or xanthine-xanthine oxidase [37, 50 53]. Nevertheless, there have been some inconsistencies in the reporting of its effects on erythrocytes, even from the same group of authors [39,54-56]. Only one out of four demonstrated G-Rh1 

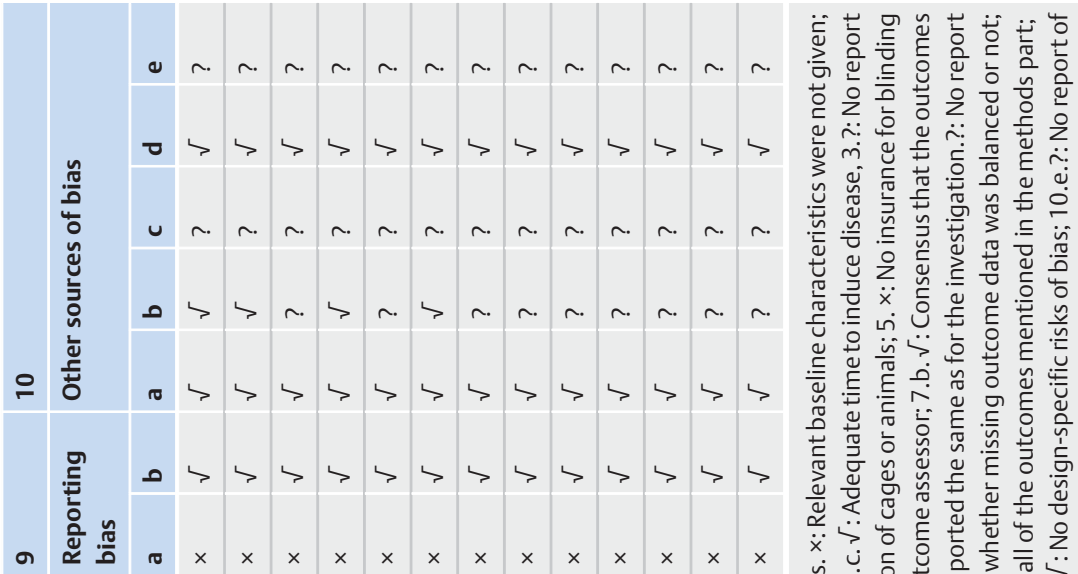
x

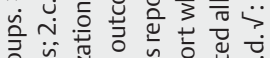
亏气 든 은.

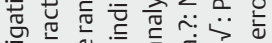

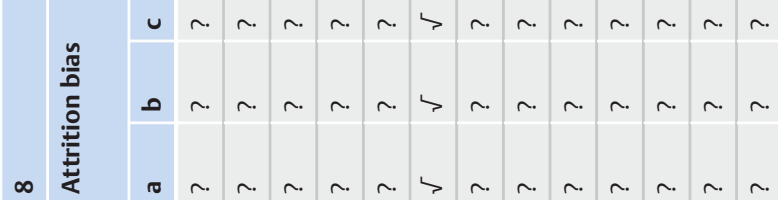

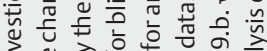

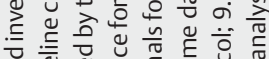

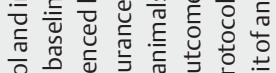

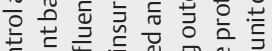

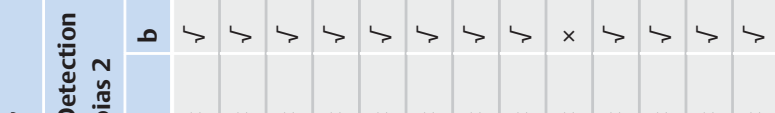

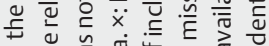

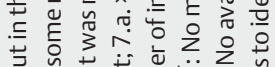

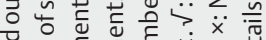
प्ष

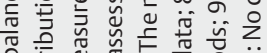

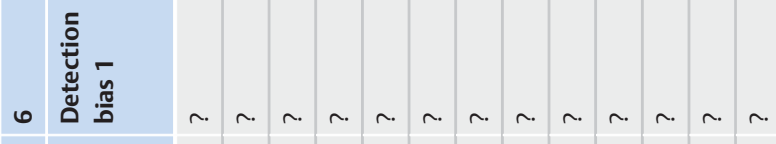
崩

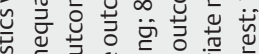

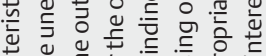

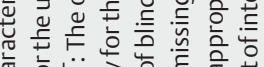

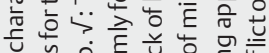

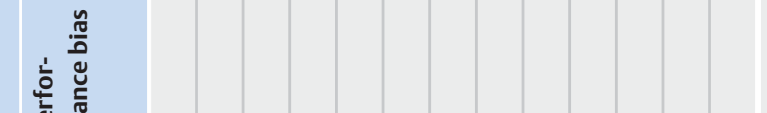
प्र

经涩

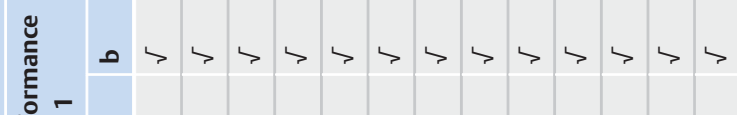

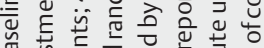

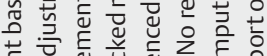

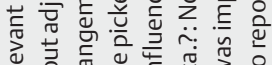

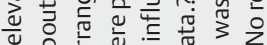

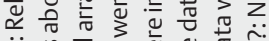

$$
\sim \text { ค. }
$$


as a prooxidant [54], which was explained later as the presence of glucose in the phosphate buffered saline somehow affected the prooxidant or antioxidant activities of G-Rh1 on AAPH-induced hemolysis [55].

Some studies showed that different stereoisomers of the same ginsenoside, i.e., 20(R) and 20(S) ginsenoside, may have different pharmacological effects $[83,84]$. Our study showed that the stereochemistry at C-20 of ginsenoside Rh 1 did not affect the neuroprotective and antiproliferative activities [20,60], but might have some effects on blood platelet aggregation and GJIC [75, 76].

Regarding the significant role of G-Rh1, knowledge of its pharmacokinetic profile and bioavailability would be a topic of interest to understand the pharmacology of ginseng and develop carrier delivery systems for bioavailability enhancement. By using the ADMET (absorption, distribution, metabolism, excretion, and toxicity) model, G-Rh1 was predicted to have favorable aqueous solubility and oral absorption in the human gastrointestinal tract [82]. However, this contradicted the results of a previous study by Lai et al. [85], which investigated the pharmacokinetic parameters and bioavailability of G-Rh1 using intravenous and intragastrical administrations in Sprague-Dawley rats. They found that this compound exhibited extremely poor absolute bioavailability of about $1 \%$ and rapid clearance with a short elimination half-life as can be seen in other protopanaxatriol ginsenosides [86]. The phenomenon might be partly explained by its main metabolic pathways, including CYP450-catalyzed mono-oxygenation, the intestinal bacteria mediated deglucosylation, and the gastric acid mediated hydration reaction [85]. To overcome this problem, Yang et al. [87] encapsulated G-Rh1 into self-microemulsions comprising P-pg and/or CYP450 inhibitory excipients. They found that the bioavailability of the formulation containing both excipients was significantly higher than those of the formulation containing P-gp inhibitory excipient alone or the free drug, confirming the CYP450-mediated metabolism of G-Rh1. Additionally, in order to treat various chronic diseases, many nanodelivery platforms have been fabricated to improve the bioavailability of ginsenosides from ginseng, such as liposomes, mixed micelles, and poly(lactic-co-glycolic acid) nanoparticles [9], which might also be applied to G-Rh1.

We choose SYRCLE's risk of bias tool to assess quality of included studies' methods because of various benefits. To reduce risks of bias for these studies, the randomization of the allocation sequence should be applied. A method of generation apparently needs to be reported. The blinding of investigators and assessors and allocation concealment also need to be guaranteed to reach reliable outcomes. Moreover, we realize that relevant baseline characteristics were not identified before starting experiments. The balance of baseline characteristics between the control and experimented groups, thus, was not verified. Consequently, it would influence the results. We recommend that the authors should report clearly the numbers of included animals in experiments and the number of animals in analysis. If there is any addition or exclusion, it should be noted with suitable reasons. On the other hand, we also agree with Hooijmans et al. [77] that the registration of all animal studies should be more common and their protocols should be published in accessible databases with the hope of improving the standards of these studies. Thereby, further studies in humans would be more accurate.
One of our study's limitations is that we missed data from other popular databases. Nevertheless, we searched many reliable databases and included a large number of articles for the qualitative analysis. We strongly believe, therefore, that our results cover nearly sufficient biological properties of G-Rh1 as above. An updated version, in the future, is obviously necessary when more studies are published.

In general, G-Rh1 has significant potential activity for anti-inflammatory and antioxidant effects. Besides, G-Rh1 has been reported to exert several positive effects on the nervous system, which potentiate the clinical application of G-Rh1 in the treatment of neurodegenerative diseases. However, the cytotoxic effects of G-Rh1 varied depending on the cell lines. There are some additional studies dealing with other separated pharmacological properties, such as estrogenic, enzymatic, anti-microorganism activities, and cardiovascular effects, but results were considerably diverged. Further investigations in randomized clinical trials are highly recommended to provide more reliable evidence for the efficacy of G-Rh1.

\section{Supporting information}

The search strategy of the systemic review is available as Supporting Information.

\section{Author Contributions}

D. N. H. T. and D. H. T. organized and wrote the manuscript. Others were involved in searching, screening the search results, translation, data collection, and making tables and figures under the supervision of Prof. K.H. and N.T.H. Each step of this study (screening title and abstract, screening full texts, and extraction of data for analysis) was performed by three independent reviewers.

\section{Conflict of Interest}

All contributing authors declare no conflicts of interest.

\section{References}

[1] Kee CH. The pharmacology of Chinese herbs. CRC Press 1999; 200: 308

[2] Xiang YZ, Shang HC, Gao XM, Zhang BL. A comparison of the ancient use of ginseng in traditional Chinese medicine with modern pharmacological experiments and clinical trials. Phytother Res 2008; 22: 851-858

[3] Baeg IH, So SH. The world ginseng market and the ginseng (Korea). J Ginseng Res 2013; 37: 1-7

[4] Accuray Research LLP. Global Ginseng Market Analysis \& Trends - Indus try Forecast to 2025. Available at https://www.researchandmarkets. com/reports/4332998. Accessed November 03, 2017

[5] Chen JK, Chen TT, Crampton L. Chinese Medical Herbology and Pharmacology. City of Industry: Art of Medicine Press; 2004

[6] Lee SM, Bae BS, Park HW, Ahn NG, Cho BG, Cho YL, Kwak YS. Characterization of Korean Red Ginseng (Panax ginseng Meyer): History, preparation method, and chemical composition. J Ginseng Res 2015; 39: 384391

[7] Park J. Recent studies on the chemical constituents of Korean ginseng (Panax ginseng CA Meyer). Korean J Ginseng Sci 1996; 20: 389-415 
[8] Chung HS, Hwang I, Oh K], Lee MN, Park K. The effect of Korean red ginseng on sexual function in premenopausal women: placebo-controlled, double-blind, crossover clinical trial. Evid Based Complement Alternat Med 2015; 2015: 91358

[9] Ganesan P, Ko HM, Kim IS, Choi DK. Recent trends of nano bioactive compounds from ginseng for its possible preventive role in chronic disease models. RSC Adv 2015; 5: 98634-98642

[10] Lee SH, Oh M, Park J, Jang SY, Cheong SH, Lee H, Moon SH. Antioxidant and anti-inflammatory activities of the ethanolic extract of fermented red ginseng marc. Food Sci Biotechnol 2015; 24: 651-657

[11] Shergis JL, Zhang AL, Zhou W, Xue CC. Panax ginseng in randomised controlled trials: a systematic review. Phytother Res 2013; 27: 949-965

[12] Nag SA, Qin J, Wang W, Wang MH, Wang H, Zhang R. Ginsenosides as anticancer agents: in vitro and in vivo activities, structure-activity relationships, and molecular mechanisms of action. Front Pharmacol 2012; 3: 25

[13] Shin BK, Kwon SW, Park JH. Chemical diversity of ginseng saponins from Panax ginseng. J Ginseng Res 2015; 39: 287-298

[14] Court WE. Ginseng, the Genus Panax. Amsterdam: CRC Press; 2000

[15] Kitagawa I, Yoshiawa M, Yoshihara M, Hayashi T, Taniyama T. Chemical studies on crude drug precession 1 . On the constituents of ginseng radix rubra (1). Yakugaku Zasshi 1983; 103: 612-622

[16] Lee S, Lee YH, Park JM, Bai DH, Jang JK, Park YS. Bioconversion of ginsenosides from red ginseng extract using Candida allociferrii JNO301 isolated from Meju. Mycobiology 2014; 42: 368-375

[17] Han BH, Park MH, Han Y, Woo L, Sankawa U, Yahara S, Tanaka O. Degradation of ginseng saponins under mild acidic conditions. Planta Med 1982; 44: 146-149

[18] Shibata S. Chemistry and cancer preventing activities of ginseng saponins and some related triterpenoid compounds. J Korean Med Sci 2001; 16: $\$ 28-\$ 37$

[19] Tawab MA, Bahr U, Karas M, Wurglics M, Schubert-Zsilavecz M. Degradation of ginsenosides in humans after oral administration. Drug Metab Dispos 2003; 31: 1065-1071

[20] Li XF, Lui CN, Jiang ZH, Ken YK. Neuroprotective effects of ginsenosides Rh 1 and Rg 2 on neuronal cells. Chin Med 2011; 6: 19

[21] Choi YJ, Yoon JH, Cha SW, Lee SG. Ginsenoside Rh1 inhibits the invasion and migration of THP-1 acute monocytic leukemia cells via inactivation of the MAPK signaling pathway. Fitoterapia 2011; 82: 911-919

[22] Li ], Du J, Liu D, Cheng B, Fang F, Weng L, Wang C, Ling C. Ginsenoside Rh1 potentiates dexamethasone's anti-inflammatory effects for chronic inflammatory disease by reversing dexamethasone-induced resistance. Arthritis Res Ther 2014; 16: 1

[23] Yoon JH, Choi Y], Lee SG. Ginsenoside Rh1 suppresses matrix metalloproteinase-1 expression through inhibition of activator protein-1 and mitogen-activated protein kinase signaling pathway in human hepatocellular carcinoma cells. Eur J Pharmacol 2012; 679: 24-33

[24] Kim YS, Kim J], Cho KH, Jung WS, Moon SK, Park EK, Kim DH. Biotransformation of ginsenoside Rb1, crocin, amygdalin, geniposide, puerarin, ginsenoside Re, hesperidin, poncirin, glycyrrhizin, and baicalin by human fecal microflora and its relation to cytotoxicity against tumor cells. J Microbiol Biotechnol 2008; 18: 1109-1114

[25] Wang Y, Hao Y, Lou J, Ma H, Qiu Q. Effect of ginsenoside Rg1 and Rh1 on the anti-tumor activity of dendritic cell. Chin J Pathophysiol 2004; 20: 1759-1764

[26] Byun BH, Shin I, Yoon YS, Kim SI, Joe CO. Modulation of protein kinase C activity in NIH $3 \mathrm{~T} 3$ cells by plant glycosides from Panax ginseng. Planta Med 1997; 63: 389-392

[27] Popovich DG, Kitts DD. Structure-function relationship exists for ginsenosides in reducing cell proliferation and inducing apoptosis in the human leukemia (THP-1) cell line. Arch Biochem Biophys 2002; 406: 1-8
[28] Quan K, Liu Q, Wan JY, Zhao Y], Guo RZ, Alolga RN, Li P, Qi LW. Rapid preparation of rare ginsenosides by acid transformation and their structure-activity relationships against cancer cells. Sci Rep 2015; 5: 8598

[29] Odashima S, Ohta T, Kohno H, Matsuda T, Kitagawa I, Abe H, Arichi S. Control of phenotypic expression of cultured B16 melanoma cells by plant glycosides. Cancer Res 1985; 45: 2781-2784

[30] Jung JS, Ahn JH, Le TK, Kim DH, Kim HS. Protopanaxatriol ginsenoside Rh1 inhibits the expression of matrix metalloproteinases and the in vitro invasion/migration of human astroglioma cells. Neurochem Int 2013; 63: 80-86

[31] Park MT, Cha HJ, Jeong JW, Lee HY, Kim SI, Baek NI, Kim O, Kim KW. Antiinvasive Activity of Ginsenoside Rh 1 and Rh 2 in the HT1080 Cells. J Ginseng Res 1998; 22: 216-221

[32] Lee YN, Lee HY, Chung HY, Kim SI, Lee SK, Park BC, Kim KW. In vitro induction of differentiation by ginsenosides in F9 teratocarcinoma cells. Eur ] Cancer 1996; 32: 1420-1428

[33] Lee YN, Lee HY, Lee YM, Chung HY, Kim SI, Lee SK, Park BC, Kim KW. Involvement of glucocorticoid receptor in the induction of differentiation by ginsenosides in F9 teratocarcinoma cells. J Steroid Biochem Mol Biol 1998; 67: 105-111

[34] He F, Ding Y, Liang C, Song SB, Dou DQ, Song GY, Kim YH. Antitumor effects of dammarane-type saponins from steamed Notoginseng. Pharmacogn Mag 2014; 10: 314

[35] Xing L, Jiang M, Dong L, Gao J, Hou Y, Bai G, Luo G. Cardioprotective effects of the YiQiFuMai injection and isolated compounds on attenuating chronic heart failure via NF-kB inactivation and cytokine suppression. J Ethnopharmacol 2013; 148: 239-245

[36] Jung JS, Shin JA, Park EM, Lee JE, Kang YS, Min SW, Kim DH, Hyun JW, Shin CY, Kim HS. Anti-inflammatory mechanism of ginsenoside Rh1 in lipopolysaccharide-stimulated microglia: critical role of the protein kinase A pathway and hemeoxygenase-1 expression. J Neurochem 2010; 115: $1668-1680$

[37] Jung JS, Kim DH, Kim HS. Ginsenoside Rh1 suppresses inducible nitric oxide synthase gene expression in IFN-gamma-stimulated microglia via modulation of JAK/STAT and ERK signaling pathways. Biochem Biophys Res Commun 2010; 397: 323-328

[38] Lee SY, Jeong JJ, Eun SH, Kim DH. Anti-inflammatory effects of ginsenoside Rg1 and its metabolites ginsenoside Rh1 and 20 (S)-protopanaxatriol in mice with TNBS-induced colitis. Eur J Pharmacol 2015; 762: 333-343

[39] Park EK, Choo MK, Han MJ, Kim DH. Ginsenoside Rh1 possesses antiallergic and anti-inflammatory activities. Int Arch Allergy Immunol 2004; 133: $113-120$

[40] Lee DC, Yang CL, Chik SC, Li JC, Rong JH, Chan GC, Lau AS. Bioactivityguided identification and cell signaling technology to delineate the immunomodulatory effects of Panax ginseng on human promonocytic U937 cells. J Transl Med 2009; 7: 34

[41] Wang Y, Wang BX, Liu TH, Minami M, Nagata T, Ikejima T. Metabolism of ginsenoside Rg1 by intestinal bacteria. II. Immunological activity of ginsenoside Rg1 and Rh1. Acta Pharmacol Sin 2000; 21: 792-796

[42] Gu W, Kim KA, Kim DH. Ginsenoside Rh1 ameliorates high fat diet-induced obesity in mice by inhibiting adipocyte differentiation. Biol Pharm Bull 2013; 36: 102-107

[43] Park YC, Lee CH, Kang HS, Kim KW, Chung HT, Kim HD. Ginsenoside-Rh1 and $\mathrm{Rh} 2$ inhibit the induction of nitric oxide synthesis in murine peritoneal macrophages. Biochem Mol Biol Int 1996; 40: 751-757

[44] Zheng H, Jeong Y, Song J, Ji GE. Oral administration of ginsenoside Rh1 inhibits the development of atopic dermatitis-like skin lesions induced by oxazolone in hairless mice. Int Immunopharmacol 2011; 11: 511-518

[45] Jang SE, Jung IH, Joh EH, Han MJ, Kim DH. Antibiotics attenuate antiscratching behavioral effect of ginsenoside Re in mice. J Ethnopharmacol 2012; 142: 105-112 
[46] Feng Y, Wang C, Cheng S, Wang X, Meng X, Li L, Du J, Liu Q, Guo Y, Meng $Y$. Ginsenoside Rh1 improves the effect of dexamethasone on autoantibodies production and lymphoproliferation in MRL/lpr mice. Evid Based Complement Alternat Med 2015; 2015: 727650

[47] Sun H, Yang Z, Ye Y. Structure and biological activity of protopanaxatrioltype saponins from the roots of Panax notoginseng. Int Immunopharmacol 2006; 6: 14-25

[48] Kim MS, Kwon B, Park MS, Ji GE. Isolation of ginsenoside Rh1 and compound $\mathrm{K}$ from fermented ginseng and efficacy assessment on systemic anaphylactic shock. Food Sci Biotechnol 2008; 17: 805-808

[49] Shin YW, Bae EA, Kim SS, Lee YC, Lee BY, Kim DH. The effects of ginsenoside Re and its metabolite, ginsenoside Rh1, on 12-O-tetradecanoylphorbol 13-acetate-and oxazolone-induced mouse dermatitis models. Planta Med 2006; 72: 376-378

[50] Jung JS, Shin JA, Park EM, Lee JE, Kang YS, Min SW, Kim DH, Hyun JW, Shin CY, Kim HS. Anti-inflammatory mechanism of ginsenoside Rh1 in lipopolysaccharide-stimulated microglia: critical role of the protein kinase A pathway and hemeoxygenase-1 expression. J Neurochem 2010; 115: $1668-1680$

[51] Jiang Y, Liu W, Wang XM, Zhong GG, Zhang W], Chen L, Zhan S, Qi H, Zhao CY, Ma XY, Yang SJ, Li H. Calcium channel blockade and anti-freeradical actions of panaxatriol saponins in cultured myocardiocytes. Acta Pharmacol Sin 1996; 17: 138-141

[52] Chae S, Kang KA, Youn U, Park JS, Hyun JW. A comparative study of the potential antioxidant activities of ginsenosides. J Food Biochem 2010; 34: $31-43$

[53] He W, Liu G, Chen X, Lu J, Abe H, Huang K, Manabe M, Kodama H. Inhibitory effects of ginsenosides from the root of Panax ginseng on stimulusinduced superoxide generation, tyrosyl or serine/threonine phosphorylation, and translocation of cytosolic compounds to plasma membrane in human neutrophils. J Agric Food Chem 2008; 56: 1921-1927

[54] Liu ZQ, Luo XY, Sun YX, Chen YP, Wang ZC. Can ginsenosides protect human erythrocytes against free-radical-induced hemolysis? Biochim Biophys Acta 2002; 1572: 58-66

[55] Liu ZQ, Luo XY, Liu GZ, Chen YP, Wang ZC, Sun YX. In vitro study of the relationship between the structure of ginsenoside and its antioxidative or prooxidative activity in free radical induced hemolysis of human erythrocytes. J Agric Food Chem 2003; 51: 2555-2558

[56] Li GX, Liu ZQ. The protective effects of ginsenosides on human erythrocytes against hemin-induced hemolysis. J Agric Food Chem 2008; 56: 1921-1927

[57] Samukawa K, Suzuki Y, Ohkubo N, Aoto M, Sakanaka M, Mitsuda N. Protective effect of ginsenosides Rg2 and Rh1 on oxidation-induced impairment of erythrocyte membrane properties. Biorheology 2008; 45: 689700

[58] Wang YZ, Chen J, Chu SF, Wang YS, Wang XY, Chen NH, Zhang JT. Improvement of memory in mice and increase of hippocampal excitability in rats by ginsenoside $\mathrm{Rg} 1$ 's metabolites ginsenoside Rh1 and protopanaxatriol. J Pharmacol Sci 2009; 109: 504-510

[59] Hou J, Xue J, Lee M, Yu J, Sung C. Long-term administration of ginsenoside Rh1 enhances learning and memory by promoting cell survival in the mouse hippocampus. Int J Mol Med 2014; 33: 234-240

[60] Lee SH, Yang SC, Park JK, Jung MW, Lee C]. Reduction of electrically evoked neural activity by ginseng saponin in rat hippocampal slices. Biol Pharm Bull 2000; 23: 411-414

[61] Dong S, Kiyama R. Characterisation of oestrogenic activity of ginsenosides in MCF-7 cells using a customised DNA microarray. Food Chem 2009; 113: 672-678

[62] Lee Y, Jin Y, Lim W, Ji S, Choi S, Jang S, Lee S. A ginsenoside-Rh1, a component of ginseng saponin, activates estrogen receptor in human breast carcinoma MCF-7 cells. J Steroid Biochem Mol Biol 2003; 84: 463-468
[63] Bae EA, Shin JE, Kim DH. Metabolism of ginsenoside Re by human intestinal microflora and its estrogenic effect. Biol Pharm Bull 2005; 28: 1903-1908

[64] Liu Y, Ma H, Zhang JW, Deng MC, Yang L. Influence of ginsenoside Rh1 and F1 on human cytochrome p450 enzymes. Planta Med 2006; 72: 126-131

[65] Etheridge AS, Black SR, Patel PR, So J, Mathews JM. An in vitro evaluation of cytochrome P450 inhibition and P-glycoprotein interaction with goldenseal, Ginkgo biloba, grape seed, milk thistle, and ginseng extracts and their constituents. Planta Med 2007; 73: 731-741

[66] Li X, Hu J, Wang B, Sheng L, Liu Z, Yang S, Li Y. Inhibitory effects of herbal constituents on P-glycoprotein in vitro and in vivo: Herb-drug interactions mediated via P-gp. Toxicol Appl Pharmacol 2014; 275:163-175

[67] Masuno H, Kitao H, Okuda H. Ginsenosides increase secretion of lipoprotein lipase by 3T3-L1 adipocytes. Biosci Biotechnol Biochem 1996; 60: 1962-1965

[68] Bae EA, Han M], Baek NI, Kim DH. In vitro anti-Helicobacter pylori activity of panaxytriol isolated from ginseng. Arch Pharm Res 2001; 24: 297-299

[69] Jeong J], Kim B, Kim DH. Ginsenoside Rh1 eliminates the cytoprotective phenotype of human immunodeficiency virus type 1-transduced human macrophages by inhibiting the phosphorylation of pyruvate dehydrogenase lipoamide kinase isozyme 1. Biol Pharm Bull 2013; 36: 10881094

[70] Gai Y, Ma Z, Yu X, Qu S, Sui D. Effect of ginsenoside Rh1 on myocardial injury and heart function in isoproterenol-induced cardiotoxicity in rats. Toxicol Mech Methods 2012; 22: 584-591

[71] Lee ES, Choi JS, Kim MS, You HJ, Ji GE, Kang YH. Ginsenoside metabolite compound $\mathrm{K}$ differentially antagonizing tumor necrosis factor-alpha-induced monocyte-endothelial trafficking. Chem Biol Interact 2011; 194: $13-22$

[72] Lee JH, Ahn JY, Shin TJ, Choi SH, Lee BH, Hwang SH, Kang J, Kim HJ, Park CW, Nah SY. Effects of minor ginsenosides, ginsenoside metabolites, and ginsenoside epimers on the growth of Caenorhabditis elegans. J Ginseng Res 2011; 35: 375-383

[73] Tachikawa E, Kudo K, Kashimoto T, Takahashi E. Ginseng saponins reduce acetylcholine-evoked $\mathrm{Na}+$ influx and catecholamine secretion in bovine adrenal chromaffin cells. J Pharmacol Exp Ther 1995; 273: 629636

[74] Siddiqi MH, Siddiqi MZ, Ahn S, Kim Y], Yang DC. Ginsenoside Rh1 induces mouse osteoblast growth and differentiation through the bone morphogenetic protein 2/runt-related gene 2 signalling pathway. J Pharm Pharmacol 2014; 66: 1763-1773

[75] Matsuda H, Kubo M, Tani T, Arichi S, Kitagawa I. Pharmacological study on Panax ginseng CA Meyer V.: Effects of red ginseng on the experimental disseminated intravascular coagulation (4). On ginsenoside-Rg3, Rh1 and Rh2. Jpn J Pharmacol 1985; 39: 123-125

[76] Zhang YW, Dou DQ, Zhang L, Chen YJ, Yao XS. Effects of ginsenosides from Panax ginseng on cell-to-cell communication function mediated by gap junctions. Planta Med 2001; 67: 417-422

[77] Hooijmans CR, Rovers MM, de Vries RB, Leenaars M, Ritskes-Hoitinga M, Langendam MW. SYRCLE's risk of bias tool for animal studies. BMC Med Res Methodol 2014; 14: 43

[78] Buettner C, Yeh GY, Phillips RS, Mittleman MA, Kaptchuk T]. Systematic review of the effects of ginseng on cardiovascular risk factors. Ann Pharmacother 2006; 40: 83-95

[79] Hur MH, Lee MS, Yang HJ, Kim C, Bae IL, Ernst E. Ginseng for reducing the blood pressure in patients with hypertension: a systematic review and meta-analysis. J Ginseng Res 2010; 34: 342-347

[80] Lee MS, Yang E], Kim Jl, Ernst E. Ginseng for cognitive function in Alzheimer's disease: a systematic review. J Alzheimers Dis 2009; 18: 339 344

[81] Geng J, Dong J, Ni H, Lee MS, Wu T, Jiang K, Wang G, Zhou AL, Malouf R. Ginseng for cognition. CDSR 2010; 12: 007769 
[82] Siraj FM, Natarajan S, Kim Y], Chun Yang D. In silico screening of ginsenoside Rh1 with PPARy and in vitro analysis on 3T3-L1 cell line. Mol Simul 2015; 41: 1219-1226

[83] Liu J, Shiono J, Shimizu K, Yu H, Zhang C, Jin F, Kondo R. 20(R)-ginsenoside Rh2, not 20(S), is a selective osteoclastgenesis inhibitor without any cytotoxicity. Bioorg Med Chem Lett 2009; 19: 3320-3323

[84] Kang DI, Lee JY, Yang JY, Jeong SM, Lee JH, Nah SY, Kim Y. Evidence that the tertiary structure of 20(S)-ginsenoside $\mathrm{Rg} 3$ with tight hydrophobic packing near the chiral center is important for $\mathrm{Na}+$ channel regulation. Biochem Biophys Res Commun 2005; 333: 1194-1201
[85] Lai L, Hao H, Liu Y, Zheng C, Wang Q, Wang G, Chen X. Characterization of pharmacokinetic profiles and metabolic pathways of 20(S)-ginsenoside Rh1 in vivo and in vitro. Planta Med 2009; 75: 797-802

[86] Han M, Sha X, Wu Y, Fang X. Oral absorption of ginsenoside Rb1 using in vitro and in vivo models. Planta Med 2006; 72: 398-404

[87] Yang F, Zhou J, Hu X, Yu SK, Liu C, Pan R, Chang Q, Liu X, Liao Y. Preparation and evaluation of self-microemulsions for improved bioavailability of ginsenoside-Rh1 and Rh2. Drug Deliv Transl Res 2017; 7: 731-737 